\title{
Author Correction: MiR-31 promotes mammary stem cell expansion and breast tumorigenesis by suppressing Wnt signaling antagonists
}

Cong Lv, Fengyin Li, Xiang Li, Yuhua Tian, Yue Zhang, Xiaole Sheng, Yongli Song, Qingyong Meng, Shukai Yuan, Liming Luan, Thomas Andl, Xu Feng, Baowei Jiao (1), Mingang Xu, Maksim V. Plikus, Xing Dai, Christopher Lengner, Wei Cui (D), Fazheng Ren, Jianwei Shuai, Sarah E. Millar \& Zhengquan Yu (i)

Correction to: Nature Communications https://doi.org/10.1038/s41467-017-01059-5, published online 19 October 2017.

The original version of this Article contained an error in Fig. 4. In the original Fig. 4a (shown below), different quadrants within the same FACS plot and between different plots contained similar unexplained groups of data points. The raw data of the original figure are not available as they were deleted at the FACS facility where the analysis was performed. The experiments have several original replicates, for which raw data are available. The experiments have also been repeated for added robustness and the new version of Fig. 4a is shown below. This has been corrected in both the PDF and HTML versions of the Article. 
Original version of Fig. 4

a

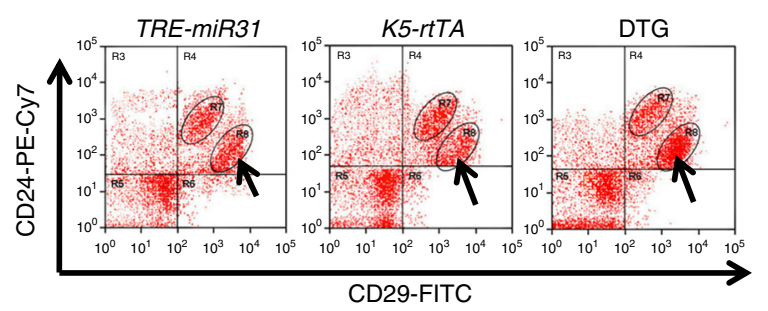

C
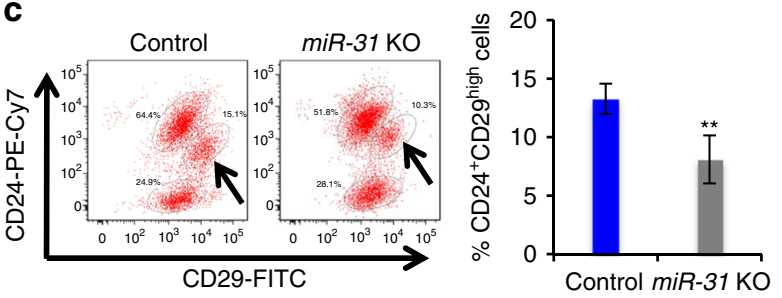

e
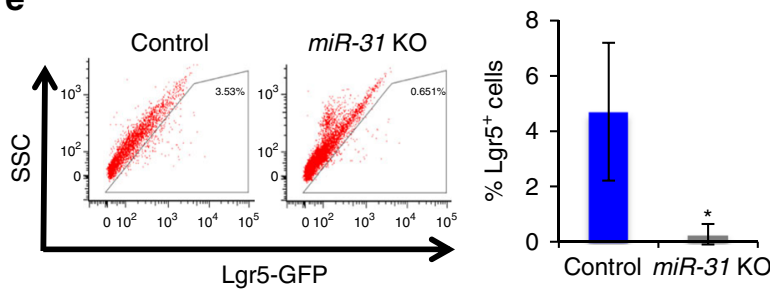

$\mathbf{f}$

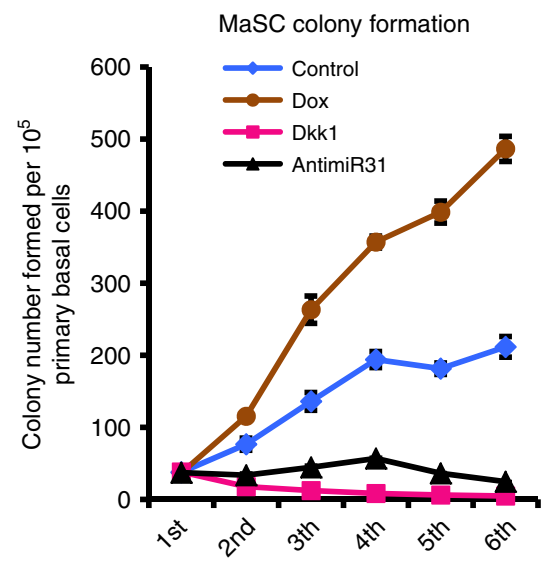

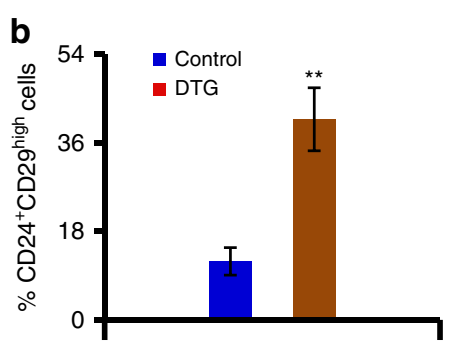

d

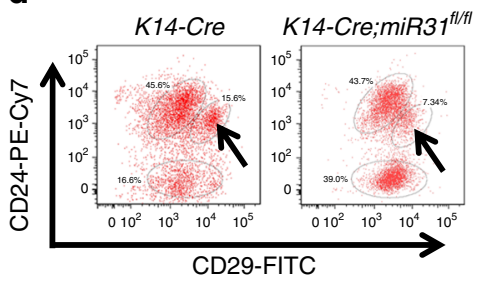

g

g $\mathrm{WT} \quad \operatorname{miR}-31 \mathrm{KO}$

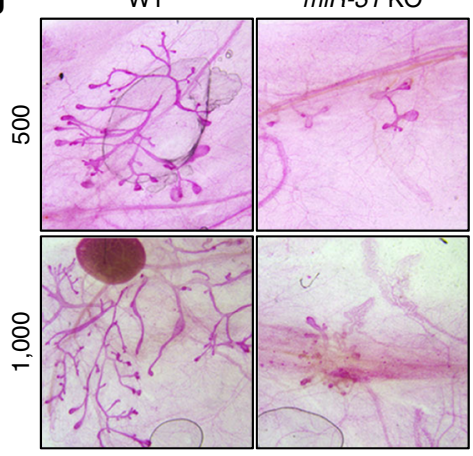

Mammary outgrowths derived from $\mathrm{Lin}^{-}$, $\mathrm{CD}_{2} 4^{+}, \mathrm{CD} 29^{\text {hi }}$ sorted mammary cells

\begin{tabular}{|c|c|c|}
\hline $\begin{array}{l}\text { Number of cells } \\
\text { injected }\end{array}$ & WT & $m i R-31 \mathrm{KO}$ \\
\hline 1,000 & $4 / 4(100 \%)$ & $2 / 4(50 \%)$ \\
\hline 500 & $4 / 5(80 \%)$ & $2 / 5(40 \%)$ \\
\hline 100 & 2/6 (33\%) & $0 / 6(0)$ \\
\hline $\begin{array}{l}\text { Repopulating } \\
\text { frequency } \\
(95 \% \mathrm{Cl})\end{array}$ & $\begin{array}{c}1 / 267(1 / 58 \\
0 \sim 1 / 123)\end{array}$ & $\begin{array}{c}1 / 1363(1 / 366 \\
0 \sim 1 / 507)\end{array}$ \\
\hline$P$ value & \multicolumn{2}{|c|}{0.00716} \\
\hline
\end{tabular}


Corrected version of Fig. 4

a

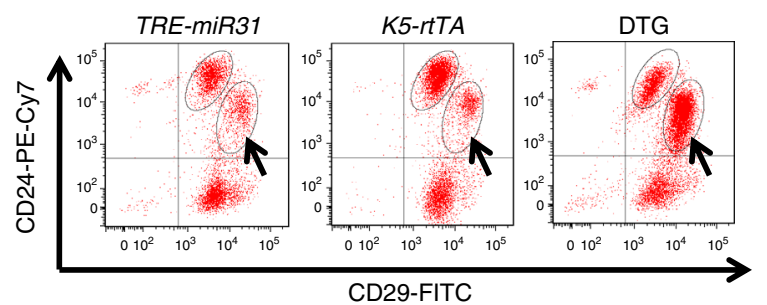

C
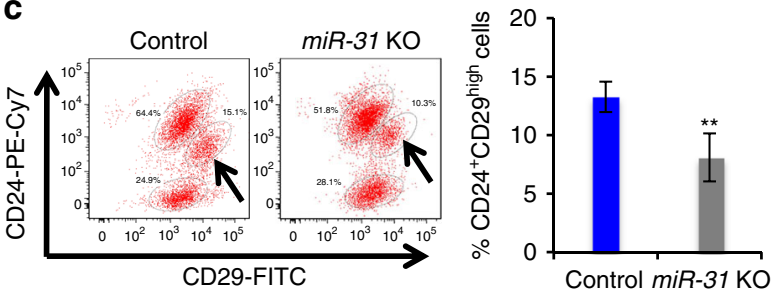

e
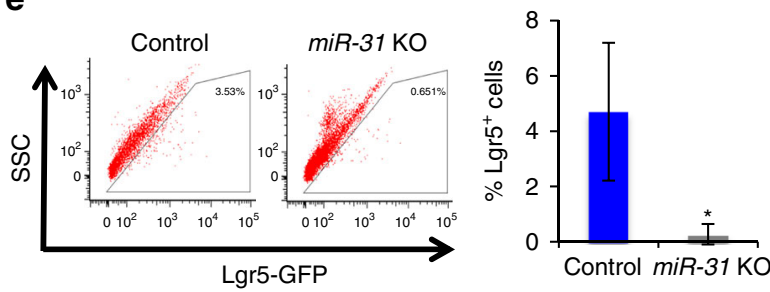

$\mathbf{f}$

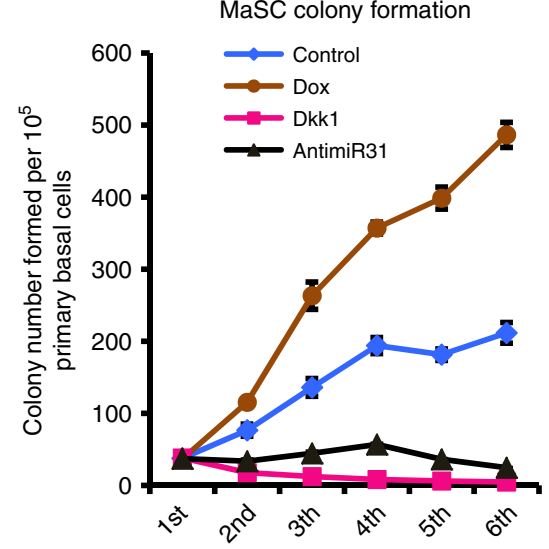

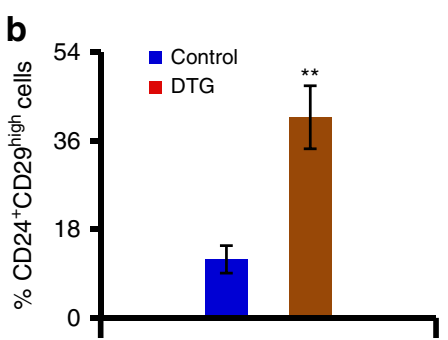

d

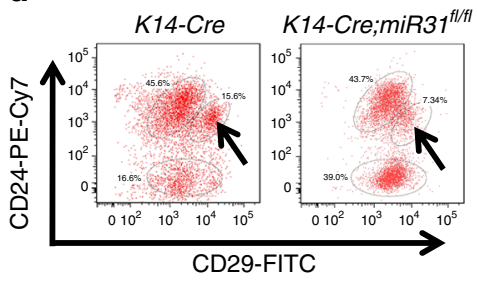

g
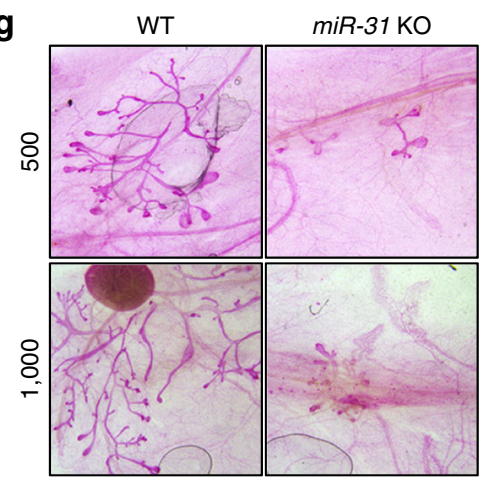

Mammary outgrowths derived from $\mathrm{Lin}^{-}$, $\mathrm{CD}_{24}{ }^{+}, \mathrm{CD} 29^{\text {hi }}$ sorted mammary cells

\begin{tabular}{ccc}
\hline $\begin{array}{c}\text { Number of cells } \\
\text { injected }\end{array}$ & WT & miR-31 KO \\
1,000 & $4 / 4(100 \%)$ & $2 / 4(50 \%)$ \\
500 & $4 / 5(80 \%)$ & $2 / 5(40 \%)$ \\
& & \\
100 & $2 / 6(33 \%)$ & $0 / 6(0)$ \\
Repopulating & $1 / 267(1 / 58$ & $1 / 1363(1 / 366$ \\
frequency \\
(95\% Cl) & $0 \sim 1 / 123)$ & $0 \sim 1 / 507)$ \\
P value & \multicolumn{2}{c}{0.00716} \\
\hline \hline
\end{tabular}

The original conclusion of a significant increase in CD24+/CD29-high mammary epithelial cells in DTG vs. control mice (as shown in Fig. 4a) remains unchanged and was already supported by the original Fig. 8i. In addition, repeats, gating strategies and raw data of Fig. $4 \mathrm{a}$ as well as gating strategies and raw data of the original Fig. 8i have been deposited in figshare (https://doi.org/10.6084/m9. figshare.13013813).

Published online: 15 October 2020 
(c) Open Access This article is licensed under a Creative Commons Attribution 4.0 International License, which permits use, sharing, adaptation, distribution and reproduction in any medium or format, as long as you give appropriate credit to the original author(s) and the source, provide a link to the Creative Commons license, and indicate if changes were made. The images or other third party material in this article are included in the article's Creative Commons license, unless indicated otherwise in a credit line to the material. If material is not included in the article's Creative Commons license and your intended use is not permitted by statutory regulation or exceeds the permitted use, you will need to obtain permission directly from the copyright holder. To view a copy of this license, visit http://creativecommons.org/licenses/by/4.0/.

(C) The Author(s) 2020 